\title{
BOTSEN, LOSKOMEN, HERHALEN. Over grenzen en denken.
}

\author{
Trees Depoorter
}

'Bis stultitia veritatem valet.'

Niet alles kan, niet alles mag, niet alles lukt. De kwestie, waar elk leven, handelen, denken - meer of minder rechtstreeks - om cirkelt is: grenzen. Wanneer grensbesef zich in het denken vertaalt, is de vorm waarin de kwestie tot uiting komt steeds: de herhaling. Plato's losgemaakte filosoof keert terug naar de grot, Nietzsches Zarathustra komt terug onder de mensen, Camus' Sisyphus loopt de berg weer af, zijn rotsblok achterna. Na elke afdaling in de hel of na elke hemelvaart keert men - meer of minder gelouterd - 'gewoon' terug naar de wereld, van waar men kwam.

De filosofische activiteit kan worden beschreven als een dringen op de grenzen van iets, een loskomen in de ruimte van het mogelijke, en een herhalen van dat iets als zodanig. In wat volgt, zal ik proberen licht te werpen op deze drie momenten: botsen, loskomen, herhalen. De held van deze tekst is 'de denker', die op exemplarische wijze deze volgorde steeds weer doorloopt.

In een eerste deel (I.) zal ik het hebben over grenzen in het algemeen: waarom en wanneer vormen grenzen een kwestie? Wat is hun rol in het denken? Vervolgens (II.) heb ik het over 'de vraag', als een instantie van het denken die de drie genoemde momenten (botsen - loskomen - herhalen) enkel in kiem bevat. Daarna (III.) ga ik kort in op de filosofie van Karl Jaspers waar deze momenten zijn ingeschreven in een heus proces, en de volgorde dus van belang blijkt. In het volgend stukje (IV.) richt ik de aandacht op het moment van de herhaling (als zin van de filosofie), om uiteindelijk (V.) ter afsluiting een tweetal implicaties te opperen.

\section{De grenskwestie.}

Twee persistenties (merken en vinden).

Als men let op de betekenis van grenzen in de ervaring en in het denken kan men twee verschillende persistenties ${ }^{2}$ ontwaren.

De eerste persistentie slaat op het telkens opnieuw merken van grenzen (in de ervaring). 
Wat men merkt, is in de eerste plaats nog niet een grens, maar het botsen. Pas in de continuilteit van het botsen ontstaat er zoiets als het herkennen van een grens, met name als het punt waarop men heeft gemerkt dat men niet verder kan of mag. Meer of minder nadrukkelijk, krijgt zijn ervaringswereld vorm in functie van de interne en externe grenzen die men ontwijkt of tegenkomt, en verlegt of bevestigt, wat bepaalde filosofen ertoe heeft gebracht bijvoorbeeld het realiteitsgehalte van de wereld precies af te meten aan de 'weerstand' die men ondervindt, of de werkelijkheid van 'zijn eigen zelf te formuleren in functie van zijn mogelijkheden. ('Mogelijkheid' is in de grond niets anders dan een andere uitdrukkingswijze voor 'grens', het gaat om twee kanten van de zelfde munt.)

Hoe persistent en constitutief het überhaupt oppoppen van grenzen in de ervaringswereld ook moge zijn: deze ervaart men steeds als specifiek. 'De' grens bestaat (daar) niet, en ook een hiërarchie valt niet op te stellen: ook al ondervindt men de éne grens als fundamenteler of problematischer dan een andere, dat maakt die andere niet minder grens. Zoniet, dan ging het blijkbaar niet om een heuse 'grens'. Niettemin staat het 'merken' van de grens in rechtevenredige verhouding met de aandacht die men eraan geeft. Dit verwijst meteen naar een ander aspect van grenzen in de ervaring: het ondervinden van een grens is nooit een 'neutrale' aangelegenheid. Op een of andere manier 'moet' men er zich toe verhouden: in zoverre het handelen, voelen, denken, oordelen, willen,... precies invulling en richting krijgen door de wijze waarop men zich verhoudt tot de mogelijkheden en onmogelijkheden die men merkt, kan men een grens definiëren als 'datgene waartoe men zich verhoudt'. Men is als het ware een 'zijn-tot-(zijn-)grenzen'.

Eén manier om zich te verhouden ten opzichte van deze steeds specifieke grenzen, is denken. Het proberen 'vinden' van grenzen überhaupt vormt een wezenlijke activiteit van het filosoferen.

De tweede persistentie slaat op het aanhoudende speuren naar grenzen (in het wijsgerig denken). Dit houdt echter meer in dan louter mentale echo's van de botsingen uit de ervaringswereld: daar waar men in de ervaring specifieke grenzen 'ondervindt', probeert men in het denken grenzen min of meer doelgericht geformuleerd te krijgen in algemeenheid, men brengt ze terug op hun mogelijkheid. Immers: het mogelijke is het medium van het denken.

Wanneer men de bedenkelijkheden, de zin, het wezen, het statuut, de aporieën, de genealogie, de structuur of de transcendentale mogelijkheidsvoorwaarden van iets probeert te formuleren, gebeurt dat steeds in functie van het 'denkbaar' maken van datgene waarop men zijn aandacht richt, en dus een aftasten van het punt waarop dat iets niet langer te doordenken valt (dit is de grens). ${ }^{3}$ Als zodanig vertaalt (het problematische van) een grens zich in het denken als 'dat wat überhaupt betekenis vergt'. Strikt formeel gesproken, is een grens precies datgene dat het mogelijke en onmogelijke scheidt: het denkbare en ondenkbare, het lichamelijke en daarbuiten, het kenbare en onkenbare, het 
toelaatbare en ontoelaatbare. In het aftastende localiseren van deze scheidslijn ontstaat voor ons betekenis, of wordt althans het gebied überhaupt getraceerd waarbinnen betekenissen (kunnen) worden uitgeprobeerd. ${ }^{4}$

Zoals alles in het denken is ook een 'gevonden grens' niets dan een hypothetische constructie, afhankelijk van zowel de specifieke ervaringen als de mate van fantasie en andere mentale vermogens van de denker in kwestie, die in de denkruimte continu wordt blootgesteld aan de allesondermijnende 'wind of thought'. Grenzen zullen dus telkens opnieuw (moeten) worden getraceerd, genuanceerd, ontmaskerd als schijn of als niet fundamenteel. Elk denken zoekt naar die grenzen die 'zo voorgoed mogelijk' zijn, maar dit is gezien 'de aard' van de grens tevergeefs: net zoals grenzen in de ervaring precies door de persistente ongrijpbaarheid van het botsen 'als grenzen' worden ervaren (men botst als het ware blindweg), verschijnen grenzen in het denken precies 'als grenzen' door de afwezigheid van duidelijkheid - een grens is het veelzeggende punt waarvoorbij de betekenis van iets ons juist ontsnapt, dit is juist dat wat betekenis vèrgt. ${ }^{5}$ Vandaar de persistentie van het telkens weer moeten her(uit) vinden van een grens in het denken.

Met andere woorden: zowel in het 'merken' als in het 'vinden' kan de pertinentie van een grens slechts liggen in zijn persistentie. Zonder het herhaaldelijke van het opbotsen tegen die specifieke grenzen in de ervaring, zonder het onophoudelijke van het (her)bepalen van de betekenis van grenzen in het denken, zouden grenzen überhaupt geen 'kwestie' vormen.

\section{Het grensbesef en de 'nuloperatie'.}

Ook het denken botst uiteraard op zijn grenzen. ${ }^{6}$ Het lukt helemaal niet alles te vatten (dit is: denkbaar te maken) of althans tot aan de grenzen van het volstrekt onbegrijpelijke of betekenisloze te dringen. Ik word omringd door zaken en kwesties die ik niet vat.

Vroeg of laat trekt het denken ook zijn wenkbrauwen op naar zichzelf. Zodra het denken op dit metaniveau springt, ontwaart het ook bij zichzelf het 'mechanisme' van de grenskwestie. Het beseffen van de grenzen zèlfs van het denken, levert zoiets als 'grensbesef' op. Dit is nog iets anders dan het louter bewustzijn van een 'specifieke' grens zodra men deze merkt of het bewustworden van de grenzen die men denkend vindt: het gaat om een inzien van de begrensdheid überhaupt. ${ }^{7}$

De vraag stelt zich uiteraard naar de betekenis van dit grensbesef, en van elk grensbewustzijn wat dat betreft. Wat kan de meerwaarde ervan zijn? Wat is het verschil tussen 'grenzen hebben' en 'grenzen hebben en het weten'? ${ }^{8}$ Als ik besef: 'dit is een grens, of: ik heb grenzen, maar ik weet het tenminste', waarop slaat dan dit 'tenminste'? 
Het meest plausibele antwoord op de vraag naar de zin van grensbesef is natuurlijk dat het de overlevingskansen verhoogt. In het speuren naar denkgrenzen oefent men zijn geest zowel in het inschatten van situaties, als in het bereid zijn vermeende grenzen in te ruilen voor andere. De klassieke wijsgerige manier om deze (praktische) 'flexibiliteit' te vertalen, is dat grensbesef vrijheid oplevert. Het losgeraken van het vaste of het veronderstelde, om aldus tot herbepaling te (kunnen) komen, zoals dat in het denken gebeurt, komt neer op een hertraceren van de grenzen met een inzicht in hun hoedanigheid. Op die manier ben ik niet alleen de vanzelfsprekendheid kwijt, maar tegelijk ben ik er van 'bevrijd' - èn ben ik het bijgevolg ook nooit kwijt geraakt: "Enkel waarvan ik vrij ben, daartoe ben ik vrij."

'Vrijheid' is echter een geladen term, die zoveel meer inhoudt en impliceert dan waar het in de beperkte context van deze tekst om gaat (met name een licht werpen op de beweging van het denken als een botsen - loskomen - herhalen). Liever dan te spreken over 'vrijheid', wil ik het een (schijnbare) nuloperatie noemen (hier kom ik helemaal op het einde nog op terug). Het resultaat van grensbesef - het 'tenminste' weten - lijkt immers niets op te leveren dan het, via een omweg (denken), kunnen bekomen (grenzen 'als' grenzen) van wat men reeds had (grenzen). Het denken komt neer op het weggaan om nergens anders te geraken dan het punt vanwaar men terug kan komen.

Grensbesef schept afstand, en aldus een 'gelegenheid' zich te verhouden tot zijn grenzen (zijn mogelijkheden en onmogelijkheden), die men - als ze niet overschrijdbaar blijken - kan aanvaarden, of net niet, natuurlijk, zoals de weerspannige protagonist van Dostojewski's Aantekeningen uit het ondergrondse:

Geen mogelijkheid - dat wil zeggen: de stenen muur! Wat voor een stenen muur? Wel, uiteraard de natuurwetten, de conclusies van physica en mathematica.(...) Natuurlijk zal ik zo'n muur niet met mijn hoofd kapot stoten als ik daar inderdaad de kracht niet toe heb, maar toch zal ik niet voor haar capituleren alleen maar omdat daar een muur staat en ik niet sterk genoeg ben. ${ }^{10}$

\section{De vraag.}

Binnen het filosofisch denken neemt het vragen klassiek een centrale plaats in. De vraag zelf is echter nog geen denken, maar zij 'doet' wel iets: ze ontsluit prompt het mogelijke (de denkruimte), tegelijk biedt ze gelegenheid tot 'sluiten' en verandert ze bovendien alles - maar tegelijk toch niets. Men kan 'de vraag' als het denkinstrument bij uitstek zien voor het omgaan met de grenskwestie, immers: de vraag laat loskomen, laat botsen en laat herhalen. Aldus bevat zij reeds in kiem en op een specifieke wijze de drie momenten (van denken/grenzen) 
ineens: zij vormt een drie-in-een, waarin het laten-botsen, -loskomen, -herhalen zich tegelijk voordoet.

Laten loskomen. Een vraag koppelt een bewering 'los' van alle vaste bepalingen. Een (ernstig genomen) vraag opent de denkruimte, waarbinnen het bevraagde als louter mogelijkheid wordt behandeld en zo vervolgens $k a n$ worden uitgespeeld tegen om het even welke andere mogelijkheid (een mogelijke tegenwerping, een potentiële bevestiging, uitbreiding, alternatief, analogie,...). Maar, hoewel ik de bewering niet meer als zodanig heb, ben ik het niet kwijt en wel precies omwille van het feit dat het in de denkruimte zit.

Met andere woorden: de vraag stript, maar smijt niets weg. Het bevat tegelijk het positief 'gegevene' als alle negaties ervan, houdt deze samen maar toch gescheiden. Wat ik ogenblikkelijk kwijt ben, zodra een punt (' $x$. ') zich heeft ingewisseld voor een vraagteken (' $x$ ?'), wordt mij even ogenblikkelijk terug aangeboden als mogelijkheid onder mogelijkheden. Het vragen opent het mogelijke en houdt het ook open. Pas dan heeft men de mentale speling nodig om überhaupt te kunnen denken.

Laten botsen. Niet àlle bepalingen worden gestript in de bevraging. Een vraag ontsluit de denkruimte immers op een specifieke wijze, in een welbepaalde richting. Een vraag initieert steeds ook, en meteen, een sluitende beweging, een 'reductie van de oneindigheid', door in haar specifiek-zijn een mogelijkheid te bieden om de bres, door de vraag geslagen, te dichten. Tussen de oneindige mogelijkheden van de denkruimte zitten minstens ook oneindig veel mogelijkheden tot sluiten. Niet àlle van de oneindige opdoemende mogelijkheden van het denken zijn relevant of adequaat in het omgaan met een vraag. In het doorvragen stuit men op verwarrende knopen, schijnbare paradoxen of momenten van onbegrip. In het filosofische denken zoekt men - zoals reeds geopperd - naar grenzen. Maar de richting van een filosofische vraag wordt nu precies bepaald door het zoeken naar die grenzen vanwaaruit dergelijke verwarring, schijn of onbegrip worden opgehelderd, of althans door het in kaart brengen van de punten waar de kwestie precies onophelderbaar blijkt. Het is pas in de mate dat dit lukt, dat een gevonden grens relevantie heeft in het denken. Het is daarom dat Kierkegaard, bij monde van Johannes Climacus, de paradox kan beschouwen als de 'hartstocht' van het denken

(...) en de denker zonder de paradox is als de minnaar zonder hartstocht: een middelmatige gezel. Maar de hoogste macht van iedere hartstocht is altijd haar eigen ondergang te willen (...). Dit is dus de hoogste paradox van het denken: iets te willen ontdekken wat het zelf niet kan denken. ${ }^{11}$ 
Met andere woorden: in het onbepaald-maken wordt herbepaling juist mogelijk, de richting zowel als de relevantie van de herbepalingen bestaat in het vinden van constitutieve grenzen. Een vraag kan als 'grensdetector' in dit proces worden ingezet - in het aftastende vragen, waarbij steeds andere mogelijkheden tegen elkaar worden uitgespeeld, wordt het mogelijk het denken te laten oplopen tegen vermoede grenzen.

Laten herhalen. Na het ontsluiten van de denkruimte en het afstemmen van de denkrichting verandert er soms bijzonder veel voor de denker. Zo kan men in het licht van de grenzen die men ondertussen heeft gelocaliseerd inderdaad komen tot een heuse herbepaling of een nieuwe betekenis van een bewering. Maar evengoed is het resultaat niets dan (dit is 'minstens') een automatische 'statuutverandering' van om het even welk antwoord (herbepaling) dat nu mogelijkerwijze volgt: het antwoord zal - in elk geval - 'sedert de vraag' sowieso een antwoord zijn.

Met andere woorden: dat wat ik heb herwonnen, heb ik niet meer 'gewoon', dit is in al zijn onwrikbare vanzelfsprekendheid, maar àls iets 'verliesbaar': ik ben het beweerde of het werkelijke weliswaar allesbehalve kwijt, maar met het denken erover is het mogelijke erin gekropen. Dit effect van de vraag wordt niet opgeheven zodra ze is verdwenen en vervangen door een antwoord. De vraag als de onlosmakelijke schaduw van het antwoord slaat zowel op de modaliteit als op de richting. Dus: een 'invraagstelling' maakt het mogelijk het bevraagde als zodanig te hernemen, de bewering te herhalen maar zonder illusies omtrent het statuut ervan: ik heb (minstens) wat ik had, maar als zodanig (modaliteit) en op dit of dat aspect bevraagd (richting).

\section{Jaspers}

Karl Jaspers (1883-1969), één van de grondleggers van de Existenzphilosophie, is een denker bij uitstek met grensbesef, die zowel aan grenzen als aan vrijheid een sleutelpositie geeft. Doorheen heel zijn oeuvre zindert zowel expliciet als impliciet de centrale rol die grenzen voor hem spelen in het leven, in de wetenschap zowel als in de filosofie. "Nergens heb ik 'het Zijn', overal stoot ik op grenzen. " ${ }^{\text {" }}$; toch vormt vrijheid als het ware een trampoline die de existentie - even - naar de Transcendentie toe kan slingeren ${ }^{13}$ : dit is kort samengevat 'de les' die Jaspers telkens weer trekt, en die hij heeft gekaderd, geduid, en beargumenteerd in een breed uitwaaierende filosofie, die zowat alle mogelijke gebieden van het bestaan in zijn denkconstructies betrekt.

Terecht heeft men Jaspers' denken een "filosofie van de filosofie",14 genoemd: de specificiteit van het filosofische denken is wellicht het thema 
waaraan in zijn oeuvre - misschien meer nog dan in dat van andere filosofen - het meeste aandacht wordt besteed ${ }^{15}$.

Dé ultieme grondvraag van de filosofie vormt voor Jaspers de vraag naar het zijn. Het probleem is dat dit zijn zich niet zomaar in heel zijn volle hoedanigheid aan ons biedt en wel om verschillende redenen. Enerzijds is dit te wijten aan het zijn zelf, dat aan ons verschijnt als fundamenteel gespleten. De breuken tussen de verschillende zijnssferen, die elk een eigen logica hebben, kunnen slechts worden overbrugd door een kwalitatieve sprong. Het zijn zelf zit met andere woorden vol grenzen, die in bepaalde gevallen door ons kunnen worden getranscendeerd, maar waartegen desalniettemin voortdurend wordt opgelopen. Anderzijds is het te wijten aan ons specifieke menszijn zelf, dat immers fundamenteel begrensd is. Niet alleen vertalen de verschillende zijnswijzen zich ook in het menselijke bestaan zelf in allerlei 'Spaltungen', breukpunten en incongruenties ${ }^{16}$, heel het denken, waarmee wij precies streven naar het éne zijn, is een zaak van de enkeling, die geworteld is in een historische situatie die steeds de vorm zowel als de inhoud van onze denkpogingen doordrenkt. Elke filosofie baant een weg van waarheid ${ }^{17}$ maar is nooit 'de' waarheid. Toch licht voor Jaspers op bepaalde ogenblikken voor ons zoiets als het absolute Zijn op - dan vormen de immanente verschijningen van de wereld zelf als het ware de taal van de volstrekt onvatbare, ons immer ontsnappende en overstijgende Transcendentie. Het denken zal - in overeenstemming met de immere onbereikbaarheid van het absolute Zijn - dus principieel onaf zijn, geen enkele kennis (hoe wetenschappelijk ook) en ook geen enkele lezing van het Transcendente in de wereld kan absoluutheid of alomvattendheid claimen. Desondanks blijft het bewegingsprincipe van de filosofie (Vernunft) een streven naar eenheid - iets waarin zij dan ook noodzakelijk zal falen.

Kort in kaart gebracht zijn er voor Jaspers drie radicaal gescheiden zijnsgebieden: het object-zijn, het ik-zijn en het op-zich-zijn.

Enkel het object-zijn, dat verwijst naar het empirische bestaan, kan object van kennis worden. Deze empirische wereld beslaat zelf verschillende domeinen; het zijn de wetenschappen die zich in deze eindeloosheid proberen te oriënteren, methodisch kennis verzamelend zowel over het anorganische, het levende, als de psychologisch onderzoekbare zieleroerselen en de objectief bestudeerbare producten van de geest. Deze 'wetenschappelijke wereldoriëntering' is cruciaal, want het is de enige 'objectieve' houvast die ons ter beschikking staat, maar dit impliceert meteen ook de begrensdheid ervan en het behoort tot de taak van een 'filosofische wereldoriëntering' om deze grenzen van het objectief kenbare te traceren en te waken over misplaatste claims op een 'Totalwissen' van de wetenschap (hier vergalloperen zowel het positivisme als het idealisme zich).

Maar de denkende mens neemt met het nauwgezette vervullen van deze 'politierol' en de relatief beperkte resultaten die dit voor zijn zijnsstreven 
oplevert, geen genoegen. In het inzien van de begrensdheid van elk kennen ${ }^{18}$, springt het individu integendeel naar een andere 'zijnssfeer', waar geen objectieve kennis kan worden verworven, en die dus niet langer wetenschappelijk te duiden valt, maar daarom niet minder 'reeël' blijkt voor het individu. Het ik 'transcendeert' het strikt empirische zelf en wordt 'mogelijke existentie'. Existentie is de grond van de vrijheid van een individu, waarover geen objectieve kennis te verwerven valt. We zijn enkel aangewezen op een aantal 'signa' (zoals vrijheid, geloof, trouw, liefde,...), die 'wijzen' op existentie, maar die omslaan in contradicties en paradoxen zodra men probeert te komen tot wetenschappelijk verantwoorde duidingen ervan. De taak van het filosofische denken is hier de existentie 'te verhelderen'. In deze verheldering wordt duidelijk wat de mogelijkheden en wat de grenzen zijn van de existentie. De existentie is immers als mogelijke existentie de grond voor een vrijzijn, waardoor het überhaupt in staat is te komen tot onvoorwaardelijkheid en waarachtigheid (in de communicatie met andere existenties en ten opzichte van zichzelf), maar anderzijds wordt de 'verwerkelijking' van deze existentie (zonder dewelke existentie leeg blijft) juist geconstitueerd in de confrontatie met een aantal onoverkomelijke grenzen, situaties waar het principieel nooit voorbij kan, ten opzichte waarvan de concrete existentie vorm krijgt. Deze noemt Jaspers Grenzsituationen (zoals het immer-in-een-situatie-zijn, dood, lijden, strijd, schuld).

Ook hier weer vormen 'grenzen' voor Jaspers een cruciale rol, want het zijn deze grenzen en de onrust die de existentie erbij ervaart, die de springplank vormen (voor het transcenderen) naar de derde zijnssfeer, het zijn-op-zich. De 'eigenlijke functie van de grens' bestaat erin 'nog immanent te zijn, maar reeds naar het Transcendente te wijzen. ${ }^{19}$ De existentie verhoudt zich immers niet enkel tot de wereld, tot zichzelf en anderen, maar steeds ook tot de Transcendentie. Dit 'absolute Zijn' is echter volstrekt onvatbaar voor het denken en is nooit rechtstreeks tegenwoordig. Het absolute zijn is ons enkel indirect nabij in een soort 'geheimtaal', de 'Chiffren', die echter onbewijsbaar zijn, onmededeelbaar, oneindig interpreteerbaar, onafdwingbaar en bovendien zelf steeds verdwijnen. Deze 'cijfertaal' verenigt Transcendentie en immanentie, maar dan op een voor de rede uiteindelijk onvatbare wijze. De grote mythes, religies en metafysische systemen hebben dit op indirecte wijze voorstelling gegeven (en kunnen vervolgens zelf ook 'cijfertekens' worden voor de existentie die er zich in verdiept). De derde functie van filosofie, met name het metafysische denken, komt dus neer op het lezen van dit 'cijferschrift', vanuit een existentiële beroering, een verheldering van de verschillende wijzen van zoeken naar het zijn als wegen naar de Transcendentie. Deze Transcendentie blijft echter de absolute grens waar elk vragen ophoudt, en waarop elke existentie en elke metafysica 'scheitert'. 
Jaspers' grensgevoeligheid blijkt vooral uit de beklemtoning van dit specifieke thema waar hij telkens op terugkomt, en dat een centrale denkfiguur bij hem vormt, met name het 'Scheitern' (het falen, het mislukken, het stranden). Zo wijdt hij het laatste hoofdstuk van zijn driedelige hoofdwerk (Philosophie) volledig aan dit fenomeen.

Hoe onvoorwaardelijk de existentie zich ook inzet om zo nauwgezet mogelijk te kennen wat er te kennen valt, te verhelderen wat er te verhelderen valt, zichzelf te verwezenlijken en waarachtige communicatie aan te gaan, de denkruimte open te houden en het onmiskenbare niet te miskennen - en wel zonder de grenzen van elk van deze sferen onrechtmatig te overschrijden door zich steeds te behoeden voor de valkuilen van zich opdringende illusies, schijnbare ultieme antwoorden, verabsoluteringen en verwisselingen, gemakzucht of vertwijfeling - desondanks zal zelfs zo'n onvoorwaardelijke existentie stranden. Deze onvoorwaardelijkheid is bovendien de mogelijkheidsvoorwaarde van 'het eigenlijke falen', het mislukken 'omdat het niet anders kan' (dat Jaspers plaatst tegenover 'het onechte falen', als het mislukken dat nìet noodzakelijk is). Op elk punt waar er getranscendeerd kan worden (met name bij het stoten op een fundamentele grens), doemt niet alleen het gevaar van de onrechtmatige grensoverschrijdingen op (illusies en verabsoluteringen), maar ook de 'onvermijdelijkheid' van het falen. Tot welke heroïsche grensoverschrijdingen en -overstijgingen de mens ook in staat blijkt, steeds zal hij botsen op deze laatste grens. Dit punt is iets dat men bovendien nooit volledig zal snappen, het falen zelf blijkt uiteindelijk onduidbaar. Toch is dit falen niet volstrekt negatief, want in dit stranden van het denken en van de existentie die zich tot het uiterste hebben ingezet, in de stilte die volgt op de opperste mislukking, flikkert er - ironisch genoeg - alsnog een hint van Transcendentie door. Het falen kan met andere woorden volgens Jaspers zelf een 'cijferteken' worden. Ik ervaar dan als existentie in dit laatste 'Scheitern' het Zijn, wat mij van de uiterste angst in de uiterste rust werpt - een ogenblik ervaar ik een gelatenheid, die even het onophoudelijke vragen stillegt en ervoor zorgt dat het 'volstaat dat Zijn is'. Maar ook deze toestand verdwijnt - uiteraard steeds weer.

Men kan ook in Jaspers' denken de drie momenten van botsen - loskomen hernemen, die hier nu centraal staan, herkennen - evenals de (schijnbare) 'nuloperatie' die met het grensbesef gepaard gaat.

Het botsen bij Jaspers. Jaspers' metafysica probeert een moeilijke synthese van immanentie en transcendentie te bewerkstelligen. Dit spruit precies voort uit een diep grensbesef. De mens van Jaspers vindt zich aan zijn lot overgelaten in een versplinterde wereld vol breuken en afgronden en tussen twee reusachtige muren: aan de éne kant de volstrekte onbevattelijkheid van de wereld, aan de andere kant die van de Transcendentie. Filosofie komt neer op het in rekenschap 
brengen van wat er tussen die muren gebeurt, steeds met het oog op deze absolute grenzen.

Het losmaken bij Jaspers. Om al de taken te kunnen vervullen die aan een filosoof worden gesteld (filosofische wereldoriëntering, verheldering van de existentie, metafysisch denken), is het volgens Jaspers in eerste en laatste plaats onontbeerlijk mentaal plaats te ruimen voor een constante 'Standpunktverschieblichkeit'. Filosofie heeft voor Jaspers een 'bevrijdende' functie - niet alleen omdat zij de mogelijke existentie wakker roept, maar ook doordat zij eerst de fundamentele grenzen (van het kenbare, van het denkbare) in kaart brengt en vervolgens - vrij van misplaatste verwachtingen - 'het oor aan de grens' legt en zo aandachtig mogelijk luistert naar wat we 'erachter' kunnen ontwaren, ondertussen bovendien ernstig te nemen wat er reeds over werd geuit in de grote metafysica's, religies en mythes - en dit zonder ooit tot definitieve conclusies daaromtrent te komen. Deze opdracht vergt noodzakelijk een ongebreidelde openheid van geest. Dit maakt pas het transcenderen mogelijk (en het denken moet transcenderen om filosofie te $\mathrm{zijn}^{20}$ ). Transcenderen betekent 'het overschrijden van de wereld in de wereld zelf': een loskomen ervan, zonder het te verliezen.

Het herhalen bij Jaspers. Het is precies met deze impliciete 'relativering van de wereldlijkheid" dat zich dan een "herintrede in de wereld"2l voltrekt. "Men moet de wereld verlaten hebben in het mogelijke en dan naar haar zijn teruggekeerd, om haar positief als wereld te hebben; in al haar luister en bedenkelijkheid". ${ }^{22}$ Het eindpunt van waarachtige filosofie kan dus niet zijn te komen tot de Transcendentie (gezien de grenzen), of het uitdokteren van een afgerond systeem (gezien de openheid van geest), maar houdt voor Jaspers een 'verandering in het zijnsbewustzijn' ${ }^{23}$ in. Deze 'terugkeer' in de wereld is de weg waarvoor de filosoof (steeds opnieuw) kiest, vanuit de voortdurende mogelijkheid ook te kunnen vluchten in een Jenseits of in het gemak van de ontkenning.

Elk 'Scheitern' kondigt een herhaling aan van deze hele beweging.

Het is op dit punt, waar de volgorde van belang blijkt en de grenskwestie als het ware een 'motief' vormt, dat Jaspers mij hier interesseert. Daar waar de vraag de drie momenten van de grenskwestie als het ware tegelijk aanreikte, maar zonder ze te actualiseren, voltrekt de grenskwestie zich in Jaspers' filosofie procesmatig: eerst het botsen - dan het vrijworden - uiteindelijk de herhaling. Dit geschiedt bij Jaspers meerbepaald op twee niveaus.

Enerzijds komt het naar voren als een soort 'mechanisme': de grenskwestie (botsen - loskomen - herhalen) voltrekt zich telkens wanneer men iets doet of denkt en er zich een principiële, onoverschrijdbare ${ }^{24}$ grens stelt en er zich dus een 'mogelijkheid tot transcenderen' (en dus ook Scheitern) biedt. 
Anderzijds krijgt het op een tweede niveau als het ware een 'hegeliaanse' kleuring: de herhaling van het basismechanisme zorgt ervoor dat men steeds 'hoger' transcendeert (en scheitert), waarbij tegelijk alle vorige grensbotsingen (en mislukkingen) worden opgenomen, om uiteindelijk in een heuse anticlimax, een apotheose in mineur, te stranden op het Zijn waarnaar men juist zoekt:

Zoals een gothische kerk, steeds spitser, eindigt als een verwijzen naar iets aan gene zijde, door haar eigen onvermogen zich nog hoger te verheffen, net zo eindigt Jaspers' filosofie, stapje voor stapje en van mislukking op mislukking, als niet meer dan een teken, reikhalzend naar dat wat, voor haar, onbereikbaar blijft. ${ }^{25}$

Deze dramatische beweging, die zich op kleine zowel als grotere schaal voltrekt, rust weliswaar op een vooronderstelling, een 'basisaxioma' van Jaspers, met name dat elke grens over zichzelf heen wijst op iets anders of iets hogers dat erachter ligt, ook al blijft het de vraag wat. ${ }^{26}$ (Of, zoals Jaspers het ergens formuleert: "het waarom van de grens is niet immanent te begrijpen. ${ }^{27}$ ) Dit verschaft heel het proces, tot op het Scheitern toe, sowieso een 'zin', die moeilijk nog voor betwisting vatbaar is. Het lijkt mij dat hier een beperking van Jaspers' denken duidelijk wordt.

Eerder dan het filosofische denken in te schakelen in een dergelijk 'proces', en het een tragisch-heroïsche zinvolheid te garanderen, wil ik het - strikt formeel - houden bij het belichten van de onderliggende 'beweging' (de loutere volgorde, het motief) - waarvan er in Jaspers' denken alvast twee instanties oplichtten. Deze beweging slaat met name op de herhaling.

\section{De herhaling.}

De zin van filosofisch denken ligt in de herhaling. Hiermee wordt niet bedoeld: de letterlijke repetitie, de identieke herhaling van een inhoud, een vorm, een kwestie, een doelstelling in het denken van een filosoof. Deze repetitie doet zich integendeel pas voor binnen het kader van een andere soort herhaling, waarover ik het nu heb en waarvan ik twee instanties wil onderscheiden: een 'eerste' herhaling en een 'tweede'.

De 'eerste herhaling'. Dit is in de eerste plaats het derde moment van een grenskwestie: nadat men zich bewust is geworden van specifieke grenzen en men door het denken is losgekomen van bepaalde zekerheden en vanzelfsprekendheden; nadat men op principiële grenzen is gebotst en deze heeft getranscendeerd; nadat men limieten heeft overschreden en doorheen de hel van het mogelijke is gegaan - volgt het moment waarop men het aldus verlorene 'herwint' of het ondertussen achter zich gelatene 'herneemt'. Dit is het moment van herhaling. Men herneemt een oorspronkelijke kwestie, weliswaar met een 
supplement aan grensbesef. Als men nu nog herhaalt wat men ervoor reeds had gezegd, gebeurt dit 'tenminste' als zodanig.

Veralgeme(n)end uitgedrukt: de activiteit van het denken komt neer op 'het proberen formuleren van iets als zodanig'. De filosoof tracht met andere woorden een ervaring of een kwestie te herhalen. Dit doet hij door te zoeken naar de grenzen van dat iets. Dit zoeken impliceert een ontsluiten van de denkruimte, waarbinnen men wordt overdonderd door oneindig veel mogelijkheden. Dit zorgt ervoor dat men loskomt van die oorspronkelijke ervaring en een afstand kan nemen tot de kwestie, waardoor men deze überhaupt pas kàn herhalen. Het uiteindelijke resultaat van filosofie komt anders geformuleerd neer op 'dat wat blijkt na de aporie'. Dit is de eerste herhaling, wat hierboven de 'nuloperatie' van het denken werd genoemd.

De 'tweede herhaling'. Vanaf de 'eerste herhaling', zal alles herhaling daarvan zijn. Deze 'tweede herhaling' voltrekt zich nadat men zich heeft gerealiseerd dat de 'eerste herhaling' allesbehalve éénmalig is. Telkens weer, telkens anders, doet zich bij elke nieuwe kwestie, bij elke nieuwe ervaring waaraan het filosofische denken zich wijdt, de zelfde beweging voor en treedt dus uiteindelijk de 'eerste herhaling' weer op.

Maar ook hier weer gaat het niet om een 'letterlijke' repetitie: elke nieuwe grenskwestie is op zich immers specifiek, èlke grens vergt betekenis, elke grenservaring is intens. Om ooit een stap verder te komen dan het botsen op een grens, moet men iedere keer weer los, en dat is ieder keer zowel vermoeiend als angstwekkend. Dit verdwijnt niet - ook niet na 'grensbesef', zelfs niet met de 'tweede herhaling'.

Wat wel verdwijnt, is de actualiteit van ons inzicht, van dat 'wat was gebleken na de aporie': "We verliezen voortdurend onze gedachten." 28 Men herkent telkens het patroon, dat men steeds weer vergeet of dat aan beklijving verliest - wat verandert is hooguit de 'snelheid' waarmee men zich de grenskwestie herinnert.

Dit laatste punt maakt een essentieel aspect van herhaling duidelijk, met name: het wezen van de herhaling is lineariteit. De 'eerste herhaling' beschrijft weliswaar een 'loop', maar daarbinnen is er een (lineaire) volgorde van momenten die wordt doorlopen: men kan niet komen tot herhaling als men niet eerst is 'losgekomen', en niet loskomen als men niet eerst is 'gebotst'. De 'tweede herhaling' beschrijft weliswaar een 'patroon', maar dat blijkt maar in een (mogelijke!) opeenvolging van instanties ervan (meerbepaald in de herhaling van de 'eerste herhaling'). Lineariteit is de mogelijkheidsvoorwaarde voor het herkennen zowel als voor het telkens weer vergeten binnen deze 'tweede herhaling'. 
Het lijkt mij hier relevant om - hoe beknopt ook - nogmaals te refereren naar Kierkegaard. In De Herhaling (1843) speelt Kierkegaard met name twee vormen van herhaling tegen elkaar uit (dit doet hij impliciet, via een aantal personages, eerder dan ze expliciet te thematiseren of te onderscheiden). Constantin Constantius, de verteller van het 'psychologische experiment', 'onderzoekt' in een eerste deel de (on)mogelijkheid van wat men 'letterlijke repetitie' kan noemen. Van geheel andere aard echter is de (on)mogelijkheid van de herhaling waar 'de jonge man' naar op zoek is, met name het herwinnen van zichzelf nadat men zich is verloren, het komen tot een 'tweede onmiddellijkheid'. Beide herhalingen blijken 'onafdwingbaar'. Maar Kierkegaard scheidt de twee radicaal. De 'beproeving' die 'de jonge man' ondergaat, loopt parallel met het moment waarop men loskomt van elke houvast; de aanleiding van de jongeman - een 'confrontatie' met zichzelf (het bedenkelijke spiegelbeeld dat hij van zichzelf krijgt in zijn liefde voor een meisje) - is analoog aan een botsen op een grens die betekenis 'vergt', en ondanks de hogere, religieuze betekenis die er bij Kierkegaard (steeds) essentieel in zit, lijkt de herhaling waar de jongeman op wacht en die hij uiteindelijk 'krijgt', analoog aan wat ik zopas de '(eerste) herhaling' heb genoemd:

Is dit geen echte herhaling? Heb ik niet alles dubbel teruggekregen? Heb ik niet mij zelf teruggekregen, en wel zò, dat ik de betekenis daarvan dubbel moet ondervinden? En wat is een herhaling van aards goed, onverschillig tegenover de bestemming van de geest, in vergelijking met een herhaling in laatstgenoemde $\operatorname{zin}^{29}$

De analogie gaat natuurlijk niet helemaal op. Tegenover de dramatische éénmaligheid van Kierkegaards 'verlossende herhaling', die zich slechts met de blikseminslag van 'de genade' of het onbevattelijke ogenblik van een 'sprong' kan voordoen (en dus een transcendente categorie is), staat hier immers 'slechts' een verschrompelde, 'immanente' versie van dit patroon: de 'herhaling van de herhaling'. De fasering die - strikt formeel gesproken - ook in het verhaal van Kierkegaards jongeman te herkennen is (het ontstaan van een voor\&na), kan zich voortdurend (liever: telkens) meer of minder intens, meer of minder ingrijpend, in een aan het denken blootgestelde ervaringswereld voordoen. De klemtoon ligt dan niet, zoals bij Kierkegaard, op de herhaling als een kwalitatief fundamenteel verschillende toestand, nadat het denken juist een ogenblik niet meer kon volgen (het is immers deze mogelijkheid überhaupt dat Kierkegaard probeert te denken met het concept van de sprong, de genade,...), maar op herhaling als het resultaat van een specifieke denkweg, als een toestand die - hoe verschillend ook - toch in het verlengde ligt van het voorgaande (dit wil zeggen: van het in de denkruimte gebracht zijn, van de tàlloze onbegrijpelijke sprongetjes die men daarbinnen maakt, van de voorlopige herarticulaties, maar òò van zoiets als het vergeten) - 
evenwel zonder daarbij, zoals bij Jaspers het geval lijkt, een zinvolheid te garanderen.

\section{Ter afsluiting.}

Wat nà de herhaling? Of los daarvan: wat zijn de gevolgen van beide herhalingen - althans wat betreft het filosofische denken? Bij wijze van afsluiting overweeg ik kort twee implicaties.

(1) Als het inderdaad zo is dat men de filosofische activiteit kan beschrijven als een dringen op de grenzen van iets, een loskomen in de ruimte van het mogelijke, en een herhalen van dat iets als zodanig, zou men ook kunnen stellen dat elke filosofische mededeling als een soort herenscènering van de grenskwestie kan worden beschouwd.

Deze ensceneringen zijn meer of minder 'performatief'. Sommige filosofen beschrijven dit proces zelf (waarop ze zijn gestoten, hoe ze zijn losgekomen, wat ze hebben teruggewonnen), andere filosofen delen enkel 'de buit' mee die ze er aan hebben overgehouden (dus enkel het moment van de herhaling als verworven inzicht in iets als iets), nog anderen stellen zich tevreden met het herkennen van de grenskwestie bij andere filosofen (zij beschrijven bijvoorbeeld ideeënhistorisch de 'tweede herhaling'). Men kan zich geroepen voelen - zoals Jaspers - vanuit een diep grensbesef, anderen aan de grenskwestie te herinneren. Men kan zelfs - zoals de vroege Wittgenstein - na het inzicht in de herhaling uitdrukkelijk beslissen te zwijgen (wat uiteraard niet minder een enscènering van de grenskwestie inhoudt).

De vraag stelt zich naar het waarom überhaupt van deze communicatie, gezien de aard van de grenskwestie (dit is dus los van de vraag naar de communiceerbaarheid ervan). De grenzen waartegen wordt opgebotst - die men merkt of vindt - behoren tot de denk- en ervaringswereld van een specifieke persoon, met bepaalde gevoeligheden en verwachtingen. Komen tot herhaling is een persoonlijke aangelegenheid, die niemand in iemands plaats kan doen; grensbesef is onafdwingbaar. Waarom dan de grenskwestie herenscèneren voor een ander? Behalve de sociologische, psychologische, morele drijfveren die gelden voor èlk communiceren, is de onophefbaarheid van onze vergeetachtigheid misschien de enige filosòfische reden of motivatie waarom men überhaupt zou proberen filosofische inzichten te communiceren: om onze inzichten iets minder snel te verliezen.

(2) Een compleet ander gevolg van de herhaling, is de noodzakelijke banaliteit van de resultaten van een denker voor een niet-filosoof of een anders denkende filosoof. Het is op dit aspect dat de 'nuloperatie' van het denken slaat. De 
filosofie heeft inderdaad te kampen met een dubbele reputatie. Enerzijds is ze berucht om wille van de zogenaamde indrukwekkende vanzelfsprekendheden waarmee ze steeds weer op de proppen komt: filosofen, zo zal een 'buitenstaander' niet zelden opmerken, zijn in staat met gezochte en moeilijke woorden de meest open deuren in te trappen. Deze reputatie valt niet te betwisten, en het zou verdacht zijn dit te willen tegenspreken of schouderophalend weg te wuiven. Men leert wel degelijk veel door dergelijke bevindingen ernstig te nemen. Het resultaat van filosoferen komt effectief neer op het debiteren van een reeks vanzelfsprekendheden, op het vatten van het blijkbare (dit is precies de herhaling). Weliswaar met de nuancering dat men het wel eerst kwijt is geraakt. Anderzijds is de filosofie berucht om wille van de indrukwekkende verwarringen waartoe zij aanleiding geeft. Ook dit lijkt mij een plausibele observatie, mits de toevoeging dat deze verwarringen slechts één 'moment' vormen in het hele denkproces. De aporie, het ten prooi zijn aan verwarring is niet helemaal het zelfde als het bedrijven van filosofie. Beide reputaties verwijzen dus telkens naar een geïsoleerd moment uit het denkproces, en daarin ligt zowel hun bekrompenheid als hun waarheid.

\section{Noten}

1 'Een herhaalde domheid heeft de kracht van waarheid.'

2 Persistentie betekent zoveel als een 'wezen' maar zonder essentialistische claims. Het gaat om een ervaringscategorie, eerder dan een ontologische. Persistenties slaan op de factuele hardnekkigheden die men opmerkt temidden van en ondanks een volstrekte contingentie, op 'dat wat voorlopig het zelfde blijkt te blijven'. Andere ervaringswerelden of ook een andere blik leveren allicht andere persistenties op.

3 'Beschrijvingen' zijn slechts filosofisch relevant, inzoverre daarmee tegelijk de grenzen oplichten van deze activiteit zelf (cfr. het onbeschrijfelijke) of indien, bijvoorbeeld, in het nog slechts kunnen beschrijven een andere grens oplicht - zoals van 'het verklaarbare' (cfr. een grens die Wittgenstein expliciet thematiseert: "Eens moet men overgaan van verklaring op louter beschrijving." - "Einmal muss man von der Erklärung auf die blosse Beschreibung kommen.", Über Gewissheit / On Certainty, Oxford, Blackwell, 1998, $\$ 189)$.

${ }^{4}$ Zo kan men bijvoorbeeld een begin maken met het zoeken naar de betekenis van kennis nà of toch door het onderscheiden van het kenbare en überhaupt onkenbare.

${ }^{5}$ Geïntensifieerd door de combinatie van het (misplaatste) verlangen te komen tot de betekenis ervan en het (niet aanvaarde) onvermogen hiertoe.

${ }^{6}$ Ook al verschijnt de denkruimte, de innerlijke ruimte in je hoofd, als je aan het denken slaat als 'het onoverschrijdbare' bij uitstek: het 'onmogelijke' schijnt onmogelijk geworden, er lijkt zich immers niets te kunnen voordoen in het denken zonder dat dit het rijk aan gedachten, denkbaarheden doet aanzwellen. Zelfs een begrip als 'het ondenkbare' is dan een zoveelste categorie van het denken en wordt zo als het ware 'opgeslorpt' door 
het mogelijke. Maar: het onoverschrijdbare (eigen aan elk 'medium') is niet hetzelfde als het geen-grenzen-hebben.

7 Maar niet van 'de' grens bij uitstek, zoals bijvoorbeeld de eindigheid, de Transcendentie,... Begrensdheid überhaupt is de grond waarop al deze afzonderlijke instanties van grensbesef pas als zodanig kunnen worden beseft (tenzij men via analogie, of als exemplarisch geval het besef van één specifieke grens extrapoleert tot grensbesef überhaupt).

${ }^{8}$ Een andere vraag is: 'zien wij grenzen omdat we bewustzijn hebben, of omgekeerd?', anders: 'wat is er eerst: grenzen of bewustzijn?'

${ }^{9}$ Wolfgang Struve, Philosophie und Transzendenz. Eine propädeutische Vorlesung, Freiburg, Rombach, 1969, p.192: "Nur wovon ich frei bin, dazu bin ich frei."

${ }_{10}$ F.M. Dostojewski, Aantekeningen uit het ondergrondse, Amsterdam, G.A. van Oorschot, 1957, p. 145-146

${ }^{11}$ Søren Kierkegaard, Wijsgerige kruimels of een kruimeltje filosofie - door Johannes Climacus, Baarn, Ambo, 1995, p.87, en iets verder: “(...) de grens is juist de smart van de hartstocht, hoewel ze haar tegelijk oproept." (p.84).

${ }^{12}$ Karl Jaspers, Philosophie III - Metaphysik, München, Piper Verlag, 1994 (1932), p. 2-3:

"Nirgends habe ich 'das Sein', überall trete ich an Grenzen."

${ }^{13}$ Karl Jaspers, Philosophie II - Existenzerhellung, p.177: "Die Freiheit ist der Hebel, an dem Transzendenz die Existenz ergreif $t^{\prime \prime}$

${ }^{14}$ Kurt Hoffman, The Basic Concepts of Jaspers' Philosophy, in: P.A. Schilpp (ed.), The Philosophy of Karl Jaspers, NY, Tudor, 1957, p. 109: "Jaspers filosofie is om zo te zeggen een filosofie van de filosofie. Met Jaspers is de filosofie tot zelfbewustzijn gekomen."

${ }^{15}$ De meest relevante werken in dit verband zijn Philosophie (3 dln.) (1932), Vernunft und Existenz (1935), Existenzphilosophie (1938) en Philosophische Logik I - Von der Wahrheit (1948).

${ }^{16}$ De mens leeft temidden van breuken en dualiteiten: object - subject; eenheid - veelheid; enkeling - andere; het algemene - het particuliere. Deze komen allemaal samen in de Grundspaltung: denken - zijn.

${ }^{17}$ Karl Jaspers, Philosophische Logik I - Von der Wahrheit, München, Piper Verlag, 1947, p. 1: "Wir leben im Zeitdasein: Wahrheit ist unser Weg"

${ }^{18}$ In Von der Wahrheit beschrijft Jaspers - in iets andere termen dan in de Philosophie, maar het komt op het zelfde neer - dit cruciale moment van 'transcenderen', met name de bevrijding van ons zijnsbewustzijn van elke specifieke kennis, als het resultaat van wat hij de 'philosophische Grundoperation' noemt, die erin bestaat dat men de vraag stelt naar datgene dat zelfs 'de horizon' omringt waarin wij steeds leven en denken (immers elke horizon wijst op iets 'daarachter'). De vraag naar het 'Umgreifende' als het alomvattende dat zelf niet meer zichtbaar is als horizon, stelt zich dan.

${ }^{19}$ Karl Jaspers, Philosophie II - Existenzerhellung, p.204. Daarom ook bestempelt Jaspers 'de grens' als 'oord van de Transcendentie' (Karl Jaspers, Philosophie III - Metaphysik, p. 13)

${ }^{20}$ Karl Jaspers, Philosophie I- Philosophische Weltorientierung, p.39

${ }^{21}$ Karl Jaspers, ibid., p.35: "Wiedereintritt in die Welt" 
${ }^{22}$ Kar Jaspers, Philosophie III - Metaphysik, p.226: "Man muss in der Möglichkeit die Welt verlassen haben und dann zu ihr zurückgekehrt sein, um sie positiv als Welt zu haben; in ihrem Glanz und ihrer Fragwürdigkeit"

${ }^{23}$ Karl Jaspers, Philosophische Logik I - Von der Wahrheit, p. 170

${ }^{24}$ Karl Jaspers, Philosophie I - Philosophische Weltorientierung, p.45: “... die Grenzen, an die ich nur stosse, <veranlassen> als solche noch kein Transzendieren."

${ }^{25}$ Jeanne Hersch over Jaspers' filosofie, geciteerd in: Jean Peamen, Raison et existence chez Karl Jaspers, Brussel, Ed. du Parthenon, 1958, p.219: "Comme l'église gothique, toujours plus mince, finit par désigner quelque chose au delà par son impuissance même à s'élever plus haut, ainsi la philosophie de Jaspers, d'étappe en étappe et d'échec en échec, finit par n'être plus qu'un signe tendu vers ce qui lui reste, à elle, inaccessible."

${ }^{26}$ Karl Jaspers, Philosophie I - Philosophische Weltorientierung, p.45: "jede Grenze lässt sofort die Frage entstehen, was darüber hinaus sei"

${ }^{27}$ Karl Jaspers, Philosophische Logik I - Von der Wahrheit, p.382

${ }^{28}$ Gilles Deleuze en Félix Guattari, Qu'est-ce que la philosophie?, Parijs, Ed. de Minuit, 1991, p.189: "Nous perdons sans cesse nos idées"

${ }^{29}$ Søren Kierkegaard, De Herhaling. Een proeve in de experimenterende psychologie door Constantin Constantius, Antwerpen, Boekengilde Die Poorte, 1958 